\title{
PRODUKSI BANDENG (Chanos chanos) MELALUI APLIKASI PUPUK ORGANIK
}

\author{
Brata Pantjara dan Erfan Andi Hendradjat \\ Balai Riset Perikanan Budidaya Air Payau \\ Jl. Makmur Dg. Sitakka No. 129, Maros 90512, Sulawesi Selatan 90511 \\ E-mail:bpantjara@yahoo.com
}

(Naskah diterima: 30 Maret 2011; Disetujui publikasi: 28 November 2011)

\begin{abstract}
ABSTRAK
Bandeng (Chanos chanos) merupakan salah satu komoditas unggulan di sektor perikanan yang berkontribusi dalam memenuhi produksi nasional. Ekspor bandeng ke beberapa negara seperti Uni Eropa dan Amerika Serikat sangat prospektif untuk dikembangkan, namun bandeng asal Indonesia kurang disukai karena terindikasi mengandung zat kimia yang dapat mengganggu kesehatan. Oleh karena itu, dalam beberapa tahun terakhir produk bandeng organik semakin meningkat karena banyaknya minat masyarakat akan produk makanan tersebut. Tujuan penelitian ini adalah untuk mengetahui pengaruh pupuk organik terhadap produksi bandeng semi intensif. Pupuk organik yang dicoba adalah pupuk organik komersial (A) dan pupuk organik non komersial (B). Pupuk organik non komersial dibuat dengan cara fermentasi dari campuran limbah sayuran, ampas tahu, pupuk kompos, dan dedak. Padat penebaran bandeng pada masing-masing perlakuan adalah 15.000 ekor/ha. Pemberian pakan dilakukan setelah bandeng berumur 2 bulan di tambak dengan dosis pakan 2\%-4\% dari bobot ikan per hari. Hasil penelitian menunjukkan bahwa pertumbuhan bandeng selama enam bulan mencapai bobot dari 1,98 g/ekor menjadi 232,4 g/ekor pada A dan $253 \mathrm{~g} /$ ekor pada B. Sintasan bandeng pada perlakuan A dan B, masing-masing mencapai $56,62 \%$ dan $60,82 \%$. Produksi bandeng pada perlakuan A dan B, masing-masing mencapai 1.974 dan $2.309 \mathrm{~kg} / \mathrm{ha}$.
\end{abstract}

KATA KUNCl: produksi, bandeng, pupuk organik, pertumbuhan

ABSTRACT: Milkfish Chanos chanos production with organic fertililizer application. By: Brata Pantjara and Erfan Andi Hendradjat

Milkfish (Chanos chanos) is one of the leading commodity in the fisheries sector that contribute to meet the national production. Milkfish exports to several countries such as the European Union and the United States is very prospective to be developed, but often milkfish from Indonesia less preferred because its shown to contain chemicals that can damage health. Therefore, in recent years, organic milkfish products increased due to the great public interest in these food products. The purpose of this study was to determine the effect of organic fertilizers on semi-intensive milkfish production. Organic fertilizers tested were commercial organic fertilizer (A) and non-commercial organic fertilizer (B). The fertilizer of non-commercial organic are made by fermentation of a mixture of vegetable and tofu waste, compost, and ground rice bran. Milksfish densities in every treatment were 15,000 ind./ha. Feeding of milkfish was done after 2 months rearing in ponds with feed dose 2\%-4\% of body weight per day. The results indicated that milkfish growth for six months to reach a weight of $1.98 \mathrm{~g} / \mathrm{ind}$. into $232.4 \mathrm{~g} / \mathrm{ind}$. (A) and $253 \mathrm{~g} / \mathrm{ind}$. (B). Survival rate of milkfish 
in $A$ and $B$ treatment can reached $56.62 \%$ and $60.82 \%$, respectivelly. Milkfish production in $A$ and $B$ eachs treatment, reached 1.974 and $2.309 \mathrm{~kg} / \mathrm{ha}$, respectively.

\section{KEYWORDS: milkfish, production, organic fertilizer, growth rate}

\section{PENDAHULUAN}

Bandeng merupakan salah satu komoditas yang mempunyai pangsa pasar cukup baik di dalam negeri dan luar negeri, terutama Timur Tengah, bahkan beberapa tahun terakhir ini sudah mulai dipasarkan di Cina dan Negara Asia lainnya (Anonimous, 2010). Pada tahun 20092010, bandeng dari Indonesia sebagian kurang diterima di pasaran Eropa dan Amerika Serikat karena disinyalir mengandung bahan kimia terutama malachite green yang dapat merusak kesehatan manusia (Anonimous, 2005). Untuk itu, perlu upaya mengurangi penggunaan bahan kimia anorganik dan menggantinya dengan penggunaan bahan organik agar produk yang dihasilkan lebih diminati dan aman dikonsumsi. Penggunaan pupuk organik dan pestisida organik dipandang lebih ramah lingkungan dibandingkan dengan penggunaan pupuk anorganik. Sehingga di masa yang akan datang produk bandeng organik perlu menjadi prioritas agar produksinya dapat dipasarkan baik dalam negeri maupun luar negeri.

Pupuk organik merupakan pupuk yang prosesnya dilakukan oleh mikroba pengurai yang mengubah bahan organik menjadi ionion yang mudah tersedia sehingga lebih cepat dimanfaatkan pakan alami. Menurut Sutanto (2002), pemberian pupuk organik selain mendapatkan hara makro seperti $\mathrm{N}, \mathrm{P}, \mathrm{K}, \mathrm{Ca}$, $\mathrm{Mg}$, dan S juga hara mikro seperti Zn, Cu, Mo, $\mathrm{Co}, \mathrm{B}, \mathrm{Mn}$, dan Fe, walaupun jumlahnya relatif sedikit. Di tambak, pupuk organik sebagai sumber nitrogen peranannya cukup besar terhadap perbaikan sifat fisik, kimia, dan biologi tanah (Martodireso \& Suryanto, 2001).

Pupuk organik dijual dalam bentuk kompos dan bahkan sudah dibuat oleh pabrik dalam bentuk padatan (butiran) dan cairan dalam kemasan atau botol plastik (Simamora \& Salundrik, 2006). Namun harga pupuk organik yang dijual di pasaran tersebut harganya sedikit lebih mahal, sehingga perlu alternatif lain penggunaan pupuk organik dengan memanfaatkan limbah organik seperti limbah pasar (terutama sayuran), dedak, ampas tahu atau limbah organik lainnya untuk dijadikan pupuk organik. Kekurangan penggunaan pupuk organik dibandingkan pupuk anorganik terutama dalam tersedianya nutrien yang rendah sehingga memerlukan pupuk dalam jumlah yang banyak (Anonimous, 2006; Gark \& Bhatnagar, 1999). Namun demikian, pupuk organik mempunyai keunggulan dalam memperbaiki sifat fisik dan biologi tanah serta ramah lingkungan. Menurut Purbayanto (2010), produk organik umumnya menghasilkan produk-produk panen yang berkualitas dan bebas dari bahan sintetis yang berbahaya. Berdasarkan permasalahan tersebut di atas, maka perlu dilakukan penelitian mengenai pupuk organik pada tambak terhadap budidaya bandeng. Penelitian ini bertujuan untuk mengetahui pengaruh pupuk organik terhadap pertumbuhan dan produksi bandeng.

\section{BAHAN DAN METODE}

Penelitian ini dilakukan di Instalasi Tambak Percobaan, Balai Riset Perikanan Budidaya Air Payau, Maros. Tambak yang digunakan sebanyak 4 petak, masing-masing berukuran $5.000 \mathrm{~m}^{2}$. Reklamasi dasar tambak dilakukan sebelum budidaya dengan tujuan menciptakan kondisi dasar tanah yang sehat. Tahapan reklamasi tersebut meliputi pengolahan tanah sampai kedalaman $10 \mathrm{~cm}$, pengeringan dasar tambak selama 5 hari pada kondisi terik matahari agar senyawa toksik pada tanah dapat teroksidasi atau nilai redoks positif (>25 mv). Perendaman untuk melarutkan senyawa toksik yang teroksidasi dan pembilasan dilakukan selesai pengeringan dasar tambak. Pemberantasan hama dari ikan dan krustase liar dengan menggunakan sapo$\mathrm{nin}$ dosis $40 \mathrm{mg} / \mathrm{L}$.

Pupuk organik yang dicoba dalam penelitian ini adalah pupuk organik komersial (A) dan pupuk organik non komersial (B). Pupuk organik komersial merupakan pupuk organik yang dibuat oleh pabrik dan dijual secara komersial di pasaran, bentuknya granuler (butiran seperti pelet). Sedangkan pupuk organik non komersial, yaitu pupuk organik yang dapat dibuat sendiri dengan memanfaatkan limbah sayuran, ampas tahu, dedak, dan pupuk kandang. Perbandingan bahan limbah untuk pembuatan pupuk organik pada 
perlakuan B ditampilkan pada Tabel 1 dan Gambar 1. Untuk mempercepat dekomposisi, bahan organik tersebut ditambah probiotik dan air, kemudian diaduk pada container fiber volume 2 ton hingga homogen dan ditutup agar terjadi fermentasi sempurna. Bahan pupuk organik tersebut diaduk setiap 7 hari selama 3-4 minggu. Probiotik dibuat dengan menambahkan bakteri asam laktat (Lactobacillus sp.) sebanyak 1 L yang dicampur dengan 2 buah nanas yang di-blender dan ditambah 10 L molase. Pupuk organik di tambak selama penelitian diberikan sebanyak 3 ton per ha. Pupuk organik diberikan pada awal dan setelah 30 hari dengan dosis $375 \mathrm{~kg} / \mathrm{ha}$.

Hewan uji yang digunakan untuk penelitian adalah bandeng gelondongan asal Bali. Padat penebaran gelondongan bandeng adalah 15.000 ekor per ha $\left(1,5\right.$ ekor $\left./ \mathrm{m}^{2}\right)$ dan bobot awal rata-rata 1,98 g per ekor. Pemberian pakan komersial (pelet) dilakukan setelah bandeng gelondongan berumur 2 bulan dan diperkirakan pakan alami di tambak sudah

Tabel 1. Komposisi bahan yang digunakan untuk pembuatan pupuk organik non komersial dalam 1 ton

Table 1. Material composition used in producing 1 ton of noncommercial organic fertilizer

\begin{tabular}{lccc}
\hline \multicolumn{1}{c}{$\begin{array}{c}\text { Komposisi } \\
\text { Composition }\end{array}$} & $\begin{array}{c}\text { Satuan } \\
\text { Units }\end{array}$ & $\begin{array}{c}\text { Volume } \\
\text { Volume }\end{array}$ & $\begin{array}{c}\text { Persentase } \\
\text { Percentage }\end{array}$ \\
\hline $\begin{array}{l}\text { Limbah sayuran } \\
\text { Vegetables waste }\end{array}$ & $\mathrm{kg}$ & 500 & 50 \\
$\begin{array}{l}\text { Dedak } \\
\text { Ground rice brand }\end{array}$ & $\mathrm{kg}$ & 250 & 25 \\
$\begin{array}{l}\text { Ampas tahu } \\
\text { Tofu waste }\end{array}$ & $\mathrm{kg}$ & 125 & 12.5 \\
$\begin{array}{l}\text { Kompos (pupuk kandang) } \\
\text { Compost (animal manure) }\end{array}$ & $\mathrm{kg}$ & 125 & 12.5 \\
$\begin{array}{l}\text { Molase (Mollases) } \\
\text { Probiotik (Probiotics) }\end{array}$ & $\mathrm{L}$ & 10 & - \\
Air (Water) & $\mathrm{L}$ & 1 & - \\
\hline
\end{tabular}
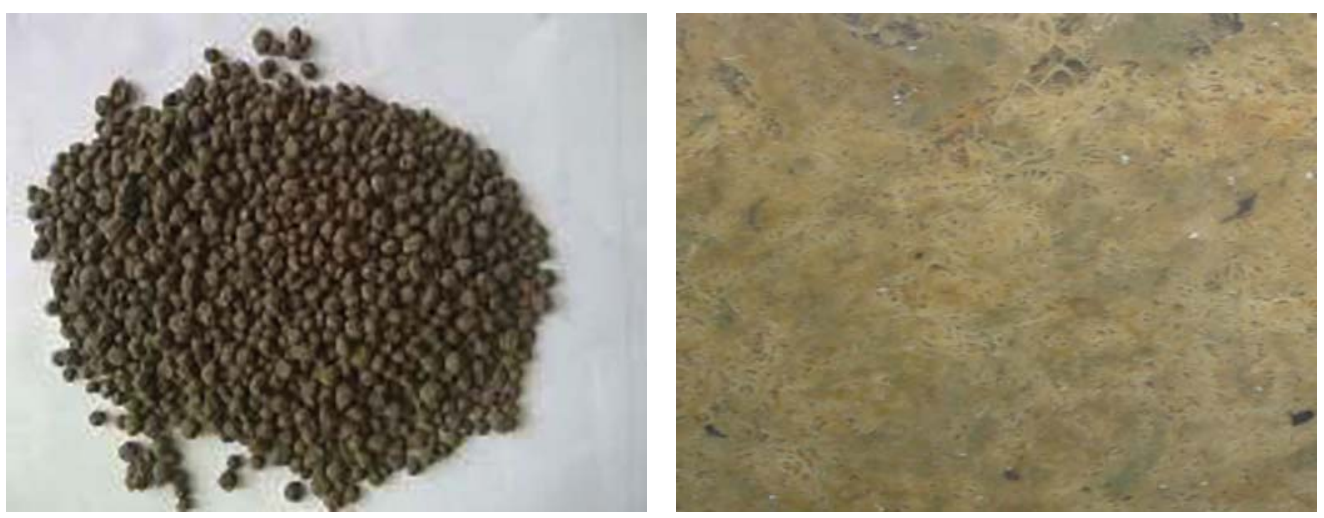

Gambar 1. Pupuk organik komersial pada perlakuan A (kiri) dan pupuk organik non komersial pada perlakuan B (kanan)

Figure 1. Commercial organic fertilizer used in treatment $A$ (left) and non-commercial organic fertilizer used in treatment B (right) 
berkurang. Pengamatan pertumbuhan bandeng dilakukan pada awal dan setiap bulan dengan lama pemeliharaan 6 bulan.

Pengamatan kualitas air meliputi suhu, salinitas, $\mathrm{pH}$, bahan organik total, $\mathrm{NH}_{3}{ }^{+}, \mathrm{NO}_{3}{ }^{2}$, $\mathrm{PO}_{4}=\mathrm{Fe}^{2+}$, dan $\mathrm{SO}_{4}=$ diamati setiap 4 minggu. Prosedur analisis air mengikuti petunjuk APHA (2005) dan Effendi (2003). Pada akhir penelitian dilakukan pengamatan terhadap rata-rata bobot, sintasan, dan produksi bandeng. Data pertumbuhan dan produksi udang windu yang diperoleh dianalisis menggunakan uji T ( $T$ test) dan untuk mengetahui kelayakan usaha dilakukan analisis ekonomi.

\section{HASIL DAN BAHASAN}

\section{Pupuk Organik}

Proses dekomposisi bahan organik dari limbah sayuran, ampas tahu, dan lainnya menghasilkan protein dan proses selanjutnya menghasilkan nutrien dan karbonat serta menambah kemasaman.

Selanjutnya nutrien tersebut digunakan untuk pertumbuhan dan reproduksi fitoplankton serta klekap untuk makanan bandeng di tambak. Hasil analisis laboratorium menunjukkan bahwa pupuk organik dari limbah sayuran dan ampas tahu yang terdekomposisi (pupuk organik non komersial) mengandung nitrogen sebesar 1,45\% dan fosfor sebesar $0,48 \%$. Komposisi kandungan pupuk tersebut sedikit lebih tinggi dibandingkan dengan kandungan pupuk organik komersial yang digunakan pada penelitian ini yaitu nitrogen $(1,22 \%)$ dan fosfor $(0,44 \%)$.

Dekomposisi limbah organik sudah terlihat pada pengamatan hari ke-10, namun limbah organik tersebut tidak semuanya terdekomposisi sempurna. Selanjutnya pengamatan hari ke-20 hingga 30, limbah organik yang terdekomposisi lebih lembek (tekstur halus) dan menghasilkan produk lain berupa cairan berwarna coklat yang kaya nutrien. Walaupun dalam penelitian ini tidak dianalisis kelimpahan mikroorganisme, namun dilaporkan oleh Atlas \& Bartha (1987), kecepatan dekomposisi limbah organik dilakukan bakteri dalam jumlah yang cukup besar. Menurut Pantjara (2008), kelimpahan bakteri dalam mengurai bahan organik disebabkan bakteri tersebut mendapat suplemen baru dari karbon yang tersedia seperti glukosa atau molase. Hasil proses dekomposisi menghasilkan asam lemak, aldehid atau bahan lainnya. Menurut Pantjara (2008), bahan organik yang terdekomposisi secara anaerob menghasilkan gas metan $\left(\mathrm{CH}_{4}\right)$ dan karbondioksida $\left(\mathrm{CO}_{2}\right)$ serta asam organik seperti asam asetat, asam propionate, asam butirat, asam laktat, dan asam suksinat. Lebih lanjut dilaporkan Sutanto (2002), sebesar 60\%-70\% kandungan karbon dari bahan organik hasil dekomposisi hilang menguap menjadi $\mathrm{CO}_{2}$ dan 30\%-40\% menjadi nitrogen yang dijumpai dalam jasad hidup termasuk mikroorganisme.

Kondisi lingkungan seperti suhu dan kelembaban membantu dalam proses dekomposisi bahan organik. Pada penelitian ini suhu yang terukur selama proses dekomposisi mencapai kisaran $32^{\circ} \mathrm{C}-62^{\circ} \mathrm{C}$. Sedangkan suhu optimum untuk dekomposisi bahan organik berkisar antara $40^{\circ} \mathrm{C}-60^{\circ} \mathrm{C}$ (Simamora \& Salundik, 2006; Coyne, 1999). Pada temperatur tersebut biasanya bakteri yang berkembang didominasi oleh bakteri mesofil dan bakteri termofil (Kaiser, 1994). Menurut Cheng \& Johnson (1998), bahwa proses dekomposisi limbah menjadi pupuk organik selain dipengaruhi oleh $\mathrm{C} / \mathrm{N}$ rasio juga suhu. Pada awal penelitian bahan pupuk mempunyai $\mathrm{C} / \mathrm{N}$ rasio 24,2 . Hal ini menunjukkan bahwa bahan pupuk tersebut mengandung karbohidrat berupa serat yang lebih tinggi dibandingkan kandungan nitrogennya.

\section{Kualitas Air}

Kualitas air merupakan komponen penting bagi kehidupan bandeng selama budidaya. Suhu air selama penelitian mencapai kisaran $27^{\circ} \mathrm{C}-31^{\circ} \mathrm{C}$ dan suhu yang optimal untuk pertumbuhan bandeng adalah $28^{\circ} \mathrm{C}-30^{\circ} \mathrm{C}$. Menurut Haslam (1995) dan Stafford (1999), fitoplankton dan diatom tumbuh dengan baik pada kisaran suhu $20^{\circ} \mathrm{C}-30^{\circ} \mathrm{C}$. Suhu yang tinggi atau rendah dapat mempengaruhi konsentrasi oksigen. Suhu yang tinggi juga mempengaruhi meningkatnya kecepatan metabolisme dan respirasi organisme akuatik, terutama peningkatan konsumsi oksigen. Kandungan oksigen yang terukur dalam penelitian ini masih dalam batas toleran yaitu mencapai kisaran 2,6-6,4 mg/L (rata-rata 3,4 mg/L). Bandeng memerlukan oksigen untuk proses metabolisme terutama diperlukan dalam penyaringan energi dari makanan. Menurut Boyd (1990), kandungan oksigen yang optimal untuk budidaya bandeng di tambak $>3$ 
$\mathrm{mg} / \mathrm{L}$. Selama penelitian $\mathrm{pH}$ air masih stabil pada kisaran 7, 1-8,0 dan $\mathrm{pH}$ air tersebut dalam kisaran yang toleran untuk pertumbuhan bandeng. Nilai pH yang baik untuk budidaya bandeng berkisar antara 6,5 hingga 9,0. Menurut Caraco et al. (1978), kondisi kemasaman dan kebasahan $(\mathrm{pH})$ mempengaruhi kandungan amonia. Semakin tinggi $\mathrm{pH}$ dan suhu dalam air menyebabkan semakin tinggi pula konsentrasi $\mathrm{NH}_{3}$.

Kandungan bahan organik terlarut dalam air selama penelitian mencapai 37,30 $\pm 6,592$ $\mathrm{mg} / \mathrm{L}$ pada pupuk organik non komersial, tampaknya hasil ini tidak jauh berbeda dengan penggunaan pupuk organik komersial yang mencapai 39,68 $\pm 6,846 \mathrm{mg} / \mathrm{L}$ (Gambar 2). Perairan dengan kandungan bahan organik terlarut di atas $26 \mathrm{mg} / \mathrm{L}$ tergolong perairan yang subur.

Nitrogen pada tambak diperlukan bagi pertumbuhan klekap karena peranannya dalam pembentukan protein yang merupakan bagian dari jasad hidup. Menurut Herbert (1999), siklus nitrogen secara alami terjadi di perairan dan peranan nitrogen dalam air sangat penting bagi organisme perairan karena berkaitan dengan tersedianya nutrien. Di tambak, amonia terjadi dari hasil pemecahan nitrogen (protein) dari pupuk organik yang diaplikasikan (Azim et al., 2003). Pada kondisi yang aerob dengan bantuan bakteri, amonia diubah menjadi nitrit dan nitrat (Boyd, 1995). Nitrat sangat penting peranannya bagi pertumbuhan klekap dan produsen primer lainnya. Bentuk ion nitrat dan amonium mempunyai peranan penting sebagai sumber nitrogen bagi plankton meskipun peranan masing-masing ion tidak sama terhadap berjenis-jenis plankton (Moriarty, 1997). Pada penelitian ini amonia yang terukur mencapai rata-rata $0,153 \pm 0,0897 \mathrm{mg} / \mathrm{L}$ dan untuk budidaya bandeng kandungan amonia yang optimal adalah kurang dari 0,1 mg/L (Gambar 2). Demikian pula dengan kandungan sulfat, fosfat, dan ferro dalam air yang masih dalam kisaran toleransi untuk budidaya bandeng (Gambar 2).

\section{Pertumbuhan Bandeng}

Penggunaan pupuk organik di tambak diharapkan dapat meningkatkan pertumbuhan bandeng. Hasil uji statistik aplikasi pupuk organik pada kedua perlakuan yang dicoba pada tambak menunjukkan tidak berbeda nyata $(P>0,05)$ terhadap pertumbuhan bandeng. Namun demikian, pertumbuhan bobot bandeng yang diukur di lapangan pada aplikasi pupuk organik non komersial (B) mencapai bobot ratarata $245,5 \mathrm{~g}$ per ekor lebih berat dibandingkan pada aplikasi pupuk organik komersial (A) yang mencapai bobot rata-rata 239,5 g per ekor (Tabel 2 dan Gambar 3). Diduga pertumbuhan bobot bandeng pada perlakuan B disebabkan bahan pupuk organik tersebut berasal dari limbah sayuran, ampas tahu, dedak, dan pupuk kandang yang yang baru terdekomposisi dan masih segar yang merupakan sumber karbohidrat dari zat organik utama dari tumbuhtumbuhan yang sesuai dengan kebutuhan nutrisi untuk pertumbuhan bandeng. Menurut Macdonald (1989), karbohidrat dari tumbuhan merupakan molekul yang mempunyai kesamaan dengan struktur hemoglobin pada ikan. Lebih lanjut dilaporkan oleh Lane \& Kohler (2007), bahwa selulosa hasil dekomposisi merupakan polisakarida terpenting dalam tumbuh-tumbuhan dan apabila mengalami perombakan menghasilkan banyak molekul gukosa dan glukosa tersebut diabsorbsi oleh sel untuk diubah menjadi energi yang tersimpan dalam bentuk glikogen meskipun dalam jumlah sedikit.

Sintasan pada bandeng yang dibudidaya dapat mempengaruhi tingkat produksi. Pada penelitian ini, bandeng pada perlakuan $B$ memperoleh sintasan yang lebih tinggi $(60,82 \%)$ dibandingkan pada A $(56,62 \%)$. Uji statistik (uji T), bahwa aplikasi pupuk organik pada kedua perlakuan menunjukkan tidak berbeda nyata terhadap produksi bandeng. Bandeng pada perlakuan A, produksi bandeng mencapai $1.974 \mathrm{~kg} / \mathrm{ha}$ sedangkan B mencapai $2.309 \mathrm{~kg} /$ ha (Tabel 2). Aplikasi pupuk organik yang berbeda mempengaruhi nilai rasio konversi pakan (RKP) pada bandeng. Aplikasi pupuk organik komersial memperoleh RKP yang lebih tinggi $(R K P=1,77)$ dibandingkan pupuk organik non komersial yang hanya mencapai RKP 1,45.

\section{Analisis Ekonomi}

Analisis ekonomi usaha budidaya bandeng melalui aplikasi pupuk organik ditampilkan pada Tabel 3a dan 3b. Dengan harga jual bandeng sebesar Rp 15.000,-/kg, maka diperoleh keuntungan sebagai berikut; aplikasi pupuk organik non komersial sebesar Rp 16.618.750,-/siklus dan aplikasi pupuk organik komersial sebesar Rp 8.067.250,-/siklus. Keuntungan yang lebih rendah pada aplikasi pupuk organik komersial disebabkan modal dalam pembelian pupuk tersebut lebih tinggi 



Gambar 2. Pengamatan kualitas air tambak pada budidaya bandeng melalui aplikasi pupuk organik

Figure 2. Water quality variation recorded in milkfish pond culture treated with organic fertilizer 
Tabel 2. Pertumbuhan, sintasan, produksi, dan rasio konversi pakan ikan bandeng selama pemeliharaan 210 hari

Table 2. Growth, survival rate, production, and feed convertion ratio of milkfish during 210 days of rearing

\begin{tabular}{|c|c|c|}
\hline \multirow{2}{*}{$\begin{array}{l}\text { Variabel } \\
\text { Variable }\end{array}$} & \multicolumn{2}{|c|}{$\begin{array}{c}\text { Aplikasi pupuk organik } \\
\text { Organic fertilizer application }\end{array}$} \\
\hline & (A) & (B) \\
\hline $\begin{array}{l}\left.\text { Luas tambak ( } \mathrm{m}^{2} / \text { petak }\right) \\
\text { Pond size }\left(\mathrm{m}^{2} / \text { pond }\right)\end{array}$ & 5,000 & 5,000 \\
\hline $\begin{array}{l}\text { Padat te bar (ekor/petak) } \\
\text { Density (ind./pond) }\end{array}$ & 7,500 & 7,500 \\
\hline $\begin{array}{l}\text { Bobot awal (g/ekor) } \\
\text { Initial weight (g/ind.) }\end{array}$ & 1.98 & 1.98 \\
\hline $\begin{array}{l}\text { Bobot akhir (g/ekor) } \\
\text { Final weight (g/ind.) }\end{array}$ & 232.4 & 253 \\
\hline $\begin{array}{l}\text { Sintasan (\%) } \\
\text { Survival rate (\%) }\end{array}$ & 56.62 & 60.82 \\
\hline $\begin{array}{l}\text { Produksi (kg/petak) } \\
\text { Production (kg/pond) }\end{array}$ & 986.9 & 1,154 \\
\hline $\begin{array}{l}\text { Rasio konversi pakan (RKP) } \\
\text { Feed conversion ratio (FCR) }\end{array}$ & 1.77 & 1.45 \\
\hline
\end{tabular}

Keterangan (Note):

(A) pupuk organik komersial dan (B) pupuk organik non komersial

(A) commercial organic fertilizer and (B) non-commercial organic fertilizer

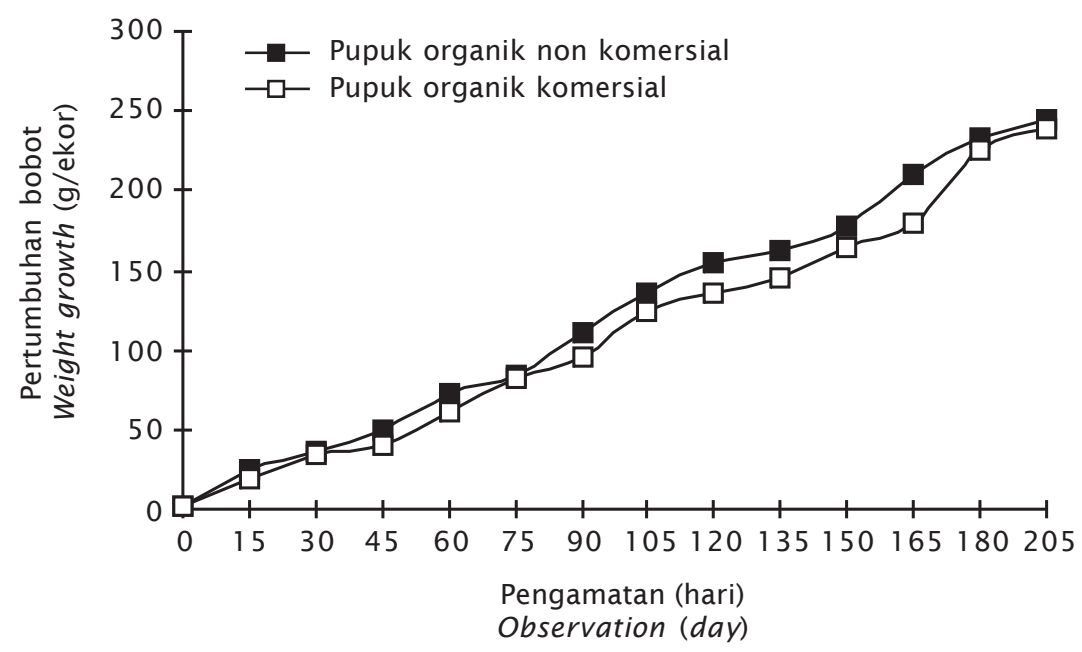

Gambar 3. Pengaruh pupuk organik terhadap pertumbuhan bandeng setiap 15 hari

Figure 3. The effect of organic fertilizers on milkfish growth during the research period 
Tabel 3a. Analisis ekonomi aplikasi pupuk organik komersial terhadap produksi bandeng

Table 3a. Economic analysis of commercial organic fertilizer application on production of milkfish

\begin{tabular}{lcccr}
\hline \multicolumn{1}{c}{$\begin{array}{c}\text { Variabel } \\
\text { Variable }\end{array}$} & $\begin{array}{c}\text { Volume } \\
\text { Volume }\end{array}$ & $\begin{array}{c}\text { Satuan } \\
\text { Unit }\end{array}$ & $\begin{array}{c}\text { Harga satuan } \\
\text { Unit price (Rp) }\end{array}$ & $\begin{array}{c}\text { Total } \\
\text { Total (Rp) }\end{array}$ \\
\hline Investasi (Invesment) & & & & $\mathbf{1 8 , 0 1 6 , 2 5 0}$ \\
- Benih (Fry) & 15,000 & ind. & 75 & $1,125,000$ \\
- Pupuk organik (Organic fertilizer) & 3,000 & $\mathrm{~kg}$ & 1,250 & $1,050,000$ \\
- Pakan (Feed) & 3,509 & $\mathrm{~kg}$ & 4,750 & $16,667,750$ \\
Penerimaan (Revenue) & 1.974 & $\mathrm{~kg}$ & 15,000 & $\mathbf{2 9 , 6 1 0 , 0 0 0}$ \\
Laba/siklus (Profit/cicle) & & & & $\mathbf{8 , 0 6 7 , 2 5 0}$ \\
Arus uang tunai (Cash flow) & & & & $16,134,500$ \\
B/C rasio (B/Cratio) & & & & \\
Rentabilitas ekonomi (\%) & & & & 1.37 \\
Economic profitability (\%) & & & & \\
Jangka pengembalian & & & & 17,003 \\
Payback period & & & & \\
Titik impas (Break even point) & & & & \\
\hline
\end{tabular}

Tabel 3b. Analisis ekonomi aplikasi pupuk organik non komersial terhadap produksi bandeng

Table 3b. Economic analysis of non-commercial organic fertilizer application on production of milkfish

\begin{tabular}{lcccr}
\hline \multicolumn{1}{c}{$\begin{array}{c}\text { Variabel } \\
\text { Variable }\end{array}$} & $\begin{array}{c}\text { Volume } \\
\text { Volume }\end{array}$ & $\begin{array}{c}\text { Satuan } \\
\text { Unit }\end{array}$ & $\begin{array}{c}\text { Harga sat uan } \\
\text { Unit price (Rp) }\end{array}$ & $\begin{array}{c}\text { Total } \\
\text { Total (Rp) }\end{array}$ \\
\hline Investasi (Invesment) & & & & $18,016,250$ \\
- Benih (Fry) & 15,000 & ind. & 60 & $1,125,000$ \\
- Pupuk organik (Organic fertilizer) & 3,000 & $\mathrm{~kg}$ & 350 & $1,050,000$ \\
- Pakan (Feed) & 3,335 & $\mathrm{~kg}$ & 4,750 & $15,841,250$ \\
Penerimaan (Revenue) & 2,309 & $\mathrm{~kg}$ & 15,000 & $\mathbf{3 4 , 6 3 5 , 0 0 0}$ \\
Laba/siklus (Profit/cicle) & & & & $\mathbf{1 6 , 6 1 8 , 7 5 0}$ \\
Arus uang tunai (Cash flow) & & & & $24,928,125$ \\
B/C rasio (B/C ratio) & & & & 1.92 \\
Rentabilitas ekonomi (\%) & & & & 92.4 \\
Economic profitability (\%) & & & & $14,219,613$ \\
Jangka pengembalian & & & & \\
Payback period & & & & \\
Titik impas (Break even point) & & & & \\
\hline
\end{tabular}

dibandingkan harga pupuk organik non komersial. Pada penelitian ini, keuntungan budidaya bandeng pada perlakuan B dua kali lipat daripada perlakuan $A$, namun keuntungannya cukup untuk menghidupi keluarga sederhana. Penggunaan biaya produksi ( $B / C$ rasio) pada perlakuan $B$ mencapai 1,84 lebih tinggi dibandingkan $A$ 
yang mencapai 1,34 . Nilai $B / C$ rasio $>1$ sehingga dapat dipastikan bahwa aplikasi pupuk organik pada budidaya bandeng di tambak merupakan salah satu alternatif pilihan dalam pemanfaatan lahan marginal dan berdaya dukung rendah.

\section{KESIMPULAN}

1. Aplikasi pupuk organik non komersial memberikan hasil yang lebih baik daripada pupuk organik komersial yang dijual di pasaran. Pertumbuhan bandeng mencapai bobot rata-rata 245,53 g/ekor; sintasan $60,82 \%$; produksi sebesar $2.309 \mathrm{~kg} / \mathrm{ha}$ dan RKP 1,45.

2. Analisis ekonomi pada aplikasi pupuk organik non komersial memperoleh keuntungan dua kali lebih tinggi yaitu sebesar Rp 16.618.750,- per siklus, B/C rasio 1,92 , rentabilitas ekonomi $92,4 \%$.

\section{DAFTAR ACUAN}

Anonimous. 2005. Awas bandeng penyebab kanker Uni Eropa: Produk ikan Indonesia beracun. http://groups.yahoo.com/ group/apakabar. Diakses tanggel 9 September 2005.

Anonimous. 2006. Biofertilizer Manual. Forum for Nuclear Cooperation in Asia (FNCA), Biofertilizer Project Group. Japan Atomic Industrial Forum, Tokyo.

Anonimous. 2010. Ekspor bandeng ke Timur Tengah. http://www.ikan bandeng. wordpress.com. Diakses Tanggal 2 April 2010.

APHA (American Public Health Association). 2005. Standard Methods for Examination of Water and Waste-water. 20 ${ }^{\text {th }}$ edition. APHA, AWWA, WEF, Washington, 1,085 pp.

Atlas, R.M. \& Bartha, R. 1987. Microbial ecology. Fundamentals and application. Second edition. The Benyamin/Cummings Publishing Company, Inc. California, 532 pp.

Zim, M.E., Milstein, A., Wahab, M.A., \& Verdegam, M.C.J. 2003. Periphyton-water quality relationship in fertilized fishponds with artificial substrat. Aquaculture, 228: 169-187.

Boyd, C.E. 1990. Water quality in ponds for aquaculture. Alabama Agricultural Experiment Station, Auburn University, Alabama, Birmingham Publishing Co USA., 482 pp.

1995. Bottom soils sediment and pond soil aquaculture. Chapman \& Hall. Auburn University Alabama, 347 pp.
Caraco, N., Tamse, A., Boutros, O., \& Valiela, I. 1978. Nutrient limitation of phytoplankton growth in brackish coastal ponds. Canadian J. Fish Aquatic Science, 44: 473476.

Cheng, W. \& Johnson, D.W. 1998. Elevated $\mathrm{CO}_{2}$, rhizosphere processes, and soil organic matter decomposition. Plant and Soil, 202: 167-174.

Coyne, M. 1999. Soil microbiology: An exploratory approach. Delmar Publisher, 62 pp.

Effendi, H. 2003. Telaah kualitas air bagi pengelolaan sumber daya dan lingkungan perairan. Penerbit Kanisius, $255 \mathrm{hlm}$.

Haslam, S.M. 1995. River Pollution and Ecological Perspective. John Wiley and Sons, Chichester, UK, 253 pp.

Gark, J,K. \& Bhatnagar, A. 1999. Effect of different doses of organic fertilizer (cow dung) on pond productivity and fish biomass in Stillwater ponds. J. of Aplplied Ichtiology, 15(1): 10-18.

Herbert, R.A. 1999. Nitrogen cycling in coastal marine ecosystems. FEMS Microbiology Review, 23(5): 563-590.

Kaiser, E.A. 1994. Significance of microbial biomass for carbon and nitrogen mineralization in soil. Z. Pfanzenernahr, Bodenk, 157: 271-278.

Lane, R.L. \& Kohler, C.C. 2007. Influence of organic fertilizer source of fatty acid composition of zooplankton and Sunshine Bass fingerlings. North American J. of Aquaculture, 69(4): 413-416.

Macdonald, R.M. 1989. An overview of crop inoculation, In R.Campbell, R. \& Macdonald, R.M. (Eds.). Microbial Inoculation of Crop Plants. IRL Press, Oxford, p. 1-9.

Martodireso, S. \& Suryanto, W.A. 2001. Terobosan teknologi pemupukan dalam era pertanian organik. Kanisius, Yogyakarta, 78 hlm.

Moriarty, D.J.W. 1997. The role of microorganisms in aquaculture ponds. Aquaculture, $151: 333-349$.

Pantjara, B. 2008. Efektivitas sumber C terhadap dekomposisi bahan organik limbah tambak udang intensif. Prosiding Seminar Nasional Kelautan IV. II: 195-199.

2009. Aplikasi pupuk organik terhadap peningkatan produktivitas tanah tambak. Prosiding Seminar Nasional Perikanan Indonesia 2009, Jakarta, 3-4 Desember 2009, $13 \mathrm{hlm}$. 
Purbayanto. A. 2010. Perikanan organik bisa mencegah pemanasan global. http:// www.purbayanto.com. Diakses tanggal 21 September 2010.

Simamora, S. \& Salundik. 2006. Meningkatkan kualitas kompos. Agro Media Pustaka, Jakarta, $64 \mathrm{hlm}$.
Stafford, C. 1999. Phytoplankton of aquaculture ponds: collection analysis and Identification, $59 \mathrm{pp}$.

Sutanto, R. 2002. Pertanian organik: Menuju pertanian alternatif dan berkelanjutan. Penerbit Kanisius, Yoyakarta. 